\title{
Digital Transformation Strategies for Achieving Operational Excellence: a Cross-Country Evaluation
}

\author{
Michele Colli \\ Aalborg University \\ colli@mp.aau.dk
}

Ole Madsen

Aalborg University

om@m-tech.aau.dk

\author{
Sergio Cavalieri \\ University of Bergamo \\ sergio.cavalieri@unibg.it
}

Brian Vejrum Wæhrens
Aalborg University
bvw@business.aau.dk

\author{
Chiara Cimini \\ University of Bergamo \\ chiara.cimini@unibg.it
}

\begin{abstract}
The last decade, the manufacturing industry has been concerned with digital transformation as a new lever for competitiveness. Nevertheless, the industrial digital transformation remains an emerging topic, which is not well understood academically and in terms of its practical implications. Due to different contextual factors and national development policies, companies from different countries adopted different strategies for supporting it. These often led to peculiar effects on the companies' operations. This paper is investigating how four large manufacturers two from Italy and two from Denmark - are strategically addressing this agenda. The aim of this research is to offer a perspective on technology transformation in diverse contexts by studying the different digital transformation strategies adopted by these companies and discussing their dependencies on contextual factors.
\end{abstract}

\section{Introduction}

The industrial digital transformation, also known as the Industry 4.0 agenda, is considered to be the new competitive lever for the manufacturing industry [1]. Started in Germany, where it has been facilitated by significant government funding, this agenda has been absorbed and formalized by the European Union (EU) [2] as well as by most of the European countries, which are supporting it through industrial policies at a national level [3]. From their side, companies adopted diverse strategies to address such transformation, with the aim of translating mere technology adoption into operational performance improvement [4] [5].

Despite globalization, national contexts remain a key influence for innovation activities. Growing proximity among national systems increases the need for understanding nation-specific differences that catalyze the adoption of diverse innovation practices at a company level (i.e. digital transformation strategies) [6] [7]. Although the different national industrial policies supporting the industrial digital transformation have already been studied and compared ([3] [8] [9]), the link between such policies and the actual digital transformation strategies adopted by companies has not been addressed.

This research aims to build an understanding of how the digital transformation of a company is affected by these different framework conditions, contributing to the existing knowledge base concerning digital transformation and providing practitioners with indications about transformation strategies to be adopted in different contexts. As this type of issue is particularly interesting when comparable contexts are taken into account [10], this paper investigates four large manufacturing companies located in two different but comparable areas (i.e. Lombardy, a region in northern Italy, and Denmark). The endogenous factors characterizing the companies' digital transformation strategies are analyzed in relation to the exogenous factors that are characterizing the national and regional contexts the companies operate in.

The paper starts by clarifying the adopted research approach and presenting the position of the European Union (EU) and, more specifically, of the Italian and Danish national contexts, in regards to the industrial digital transformation. The related exogenous factors are mapped (Table 1) according to 
the key institutional factors concerning innovation in the information technology domain [11], as this represents the foundation for the current industrial digital transformation. The four industrial cases are then presented and the endogenous factors characterizing the adopted digital transformation strategies are mapped according to the different digital dimensions they are related to (Table 2). Eventually, the dependencies between the identified exogenous and endogenous factors are discussed and further research needs are suggested.

\section{Research approach}

This research consists of a multiple case study investigation performed by two research groups in two different areas (i.e. Lombardy region in Italy and Denmark). These two contexts have been addressed in this investigation (i.e. exogenous factors) as they represent comparable areas, due to the similar dimension and GDP. The industrial cases, investigated in relation to their digital transformation strategy (i.e. endogenous factors), have been selected among global discrete manufacturers of the region as large and multinational firms have historically been more active in operationalizing it due to their availability of resources dedicated to innovation as well as internal skills to cope with it. Chosen companies are all successfully integrating and using new technologies to enable the availability of information and translate it into operational performance improvement. Furthermore, these are collaborating directly and extensively with universities and, in particular, with the authors. For this reason, the authors have been able to collect insightful information about their different digital transformation strategies.

In order to structure the investigation and to avoid interpretation biases, there has been an exchange of staff and common information mapping frameworks for both exogenous and endogenous factors have been shared. This ensured an objective evaluation of the companies' strategies supporting the validity of the case study results [12] [13].

\subsection{Exogenous factors mapping}

The exogenous factors characterizing the two addressed national contexts have been gathered through extant literature and expert interviews to stakeholders involved in the national digital transformation agenda of the two addressed countries. The collected information has been mapped according to the "institutional factors in information technology innovation" framework proposed by King et al. [11] (Table 1, shown at the end of the paper). Such a framework has been chosen due to its specific focus on information technology innovation, which is the foundation of the current digital transformation. According to that, exogenous factors can be related to six different categories:

Knowledge building, as the provision of the financial basis for the development of the scientific and technical knowledge necessary to sustain innovation;

Knowledge deployment, as the dissemination of knowledge in the form of individuals (i.e. experts) or knowledge repositories (i.e. documentation) through government entities or private institutions;

Subsidy, as the provision of targeted resources (e.g. funding or tax breaks for the acquisition of innovative products) to defray costs or risks concerning innovation;

Mobilization, as the encouragement towards specific thinking concerning the innovation process;

Innovation directive, as an institutional directive requiring the production and use of innovation;

Standard setting, as the provision of regulations or constraints concerning the use of standards.

\subsection{Endogenous factors mapping}

The endogenous factors concerning the digital transformation strategies of the different industrial cases have been gathered from the authors' previous - and ongoing - collaborations with the case companies and from interviews with the company responsible for the digital transformation agenda.

The collected information has been mapped according to a digital maturity assessment model (Table 2), as there is a consensus concerning their use as a strategic initiative for structuring the digital transformation of an organization across its different dimensions [14]. The adopted model (i.e. 360 Digital Maturity Assessment) [15] takes into account five dimensions, such as governance, competences, technology, connectivity and value creation.

Governance concerns the organizational and managerial aspects of the transformation, such as the transformation team and how pilot activities are addressed.

Competences concern the way skills needed to support digital transformation projects as well as the use of digital technologies are available, either through internal training practices (or hiring) or through external partnerships.

Value creation concerns the way digitalization is - or is willing to be - used to support the company's competitiveness. This dimension concerns information such as the transformation scope, its 
objective (i.e. either problem solving - solution development at the point of demand - or extended potential enabling), the value creation mechanism (i.e. how the increase of digital level is translated into value for the company) and the key performance indicators that the transformation addresses.

Technology concerns the data processing capabilities and what these are enabling, such as information visibility through cloud-based platforms for the collection, storage and visualization of data or the understanding of further insights through the use of analytic tools.

Connectivity concerns IT integration both at a vertical and horizontal level enabling, respectively, data sharing within the organization from the machine to the management level and across the company's supply chain.

Collected information concerning each dimension is clustered in a number of sub-dimensions, to enable a more detailed mapping and, therefore, support the comparison among the investigated cases in relation to their digital transformation strategies.

\section{Transforming European manufacturers: how the European Union is dealing with the digital transformation}

The industrial sector is of key importance for the EU economy, as it catalyzes the occupation in other sectors and acts as a driver of growth and sustainable development for the European countries [2]. However, over the last 40 years, the industrial contribution to the EU economy has been diminished by about $30 \%$, and in 2014 the value added by the manufacturing industry to the EU economy consisted of a share of $15.3 \%$ [2]. This decline caused by the introduction of automation and the offshoring phenomenon, since companies from Western countries moved their labor-intensive activities (e.g. manufacturing) to Far Eastern countries, and reorienting home-based activities to high-value activities [16] [17].

According to the EU [2], this issue has been addressed in 2008 by identifying the use of digital technologies as a development lever, and supporting activities concerning "the smart use of ICT and the integration of SMEs into digital value chains". In 2012, the European Commission stated, in its Industrial Policy Communication, six development priorities which partly related to the use of digital technologies, for achieving, as a target for 2020, a $20 \%$ share of value added in the EU by manufacturing industry. In 2014, the EU strengthened its support concerning the digital transformation of the manufacturing industry by formalizing an Industry 4.0 agenda and supporting it through the $€ 80$ billion Horizon 2020 research program. In the following months, most of the European countries formulated their own industrial digital transformation national plans accordingly [3]. Because of that, the digital transformation currently represents the main innovation focus for most of the European manufacturers, and these national plans represent the exogenous factors influencing it.

\section{1. "Piano nazionale Industria 4.0": the Italian agenda}

The Italian government formalized in 2016 what was termed as "Piano nazionale Industria 4.0" in order to provide companies both with guidelines and support concerning the digital transformation [18]. The key aspect of this 18-billion Euro national plan (2017-2020) consisted in the enabling of financial incentives for companies to buy (well-specified) physical equipment related to the Industry 4.0 enabling technologies (e.g. [20]). This was meant to provide companies with the opportunity to renovate their manufacturing equipment and, as much of it was produced in Italy, to boost the national economy at the same time. During 2018, to close the gap generated by a strong focus on technologies (and on how to benefit from financial incentives) and how to effectively use such technologies, the national plan has been redirected towards the concept of "Impresa 4.0" (i.e. Enterprise 4.0). This move consisted of extending the focus of the national plan to the whole enterprise, integrating elements such as the human capital and the need for training. To further support that, the "innovation manager" figure has been introduced in 2019 for guiding companies in their transformation process. Half of his or her payroll within a company is financed by the government (for a maximum of 40000 Euro for small companies and 25000 Euro for medium companies). In addition to this figure, in order to support companies in identifying key activities to perform to tackle their digital transformation, local institutions such as Confindustria (i.e. Italian industrial association), in collaboration with local universities, started performing digital maturity assessments to their industrial partners (Figure 1). Furthermore, universities have been financed for a number of projects concerning the development of digital technologies. The current activities (2019 and 2020) concern the realization of a structured system to sustain, at a national, regional and local level, companies in their digital transformation. This system will be aligned with EU centers and involve 
national institutions (e.g. Confindustria and local chamber of commerce) and universities. It will consist of several digital innovation hubs for detecting company needs and provide generic support, eight competence centers for providing indepth support concerning specific technologies and many "punti impresa digitale" (i.e. digital enterprise points) for supporting small companies in technology implementation projects. The activities of such system will cover awareness, training, demonstration and technology transfer projects, while actual research will remain within universities and research centers.

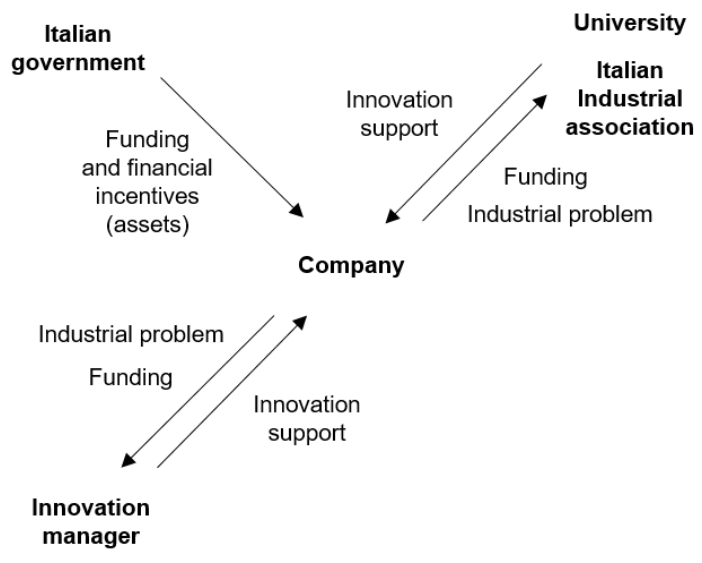

Figure 1. Structure of the Italian agenda

\section{2. "MADE": the Danish agenda}

In order to stop Danish manufacturing companies in offshoring production activities in low labor cost countries, the Danish government joined in 2009 the EU initiative "ManuFuture", which was aiming at improving the competitiveness of the European manufacturing industry [21]. Around the same time, the national project "Manufacturing 2025" highlighted, in its report, the need for keeping manufacturing in Denmark and provided five guidelines for doing so [21]. The activities concerning "ManuFuture" have been operationalized, following the guidelines from "Manufacturing 2025", through a collaboration between the Confederation of Danish Industry (i.e. Danish industrial association) and several Danish industrial and academic partners. These activities led to the launch of MADE (i.e. the manufacturing academy of Denmark), an 80-million Euro (2014-2021) national platform for supporting activities concerning the development of the Danish manufacturing industry. This platform engaged Danish universities and their laboratories as well as research and technology organizations (RTOs) to address, through research and demonstrator projects, the needs from the industrial partners joining - and partly sponsoring - the platform. Its first activities, which contains some elements of the integration of IT in production, have been grouped in the MADE SPIR (i.e. strategic platform for innovation and research) program, initiated in 2014. In 2017, due to its success and to the increasing interest in the Industry 4.0 agenda, the MADE DIGITAL program has been launched with a dedicated focus on digitalization, for supporting companies in their digital transformation. Each program has been divided into a number of work packages, addressing different topics - or the same topic at different levels of depth - according to the needs and interests of the industrial partners. Each work package, according to the number of industrial partners involved, has funding to buy research hours (either from Ph.D. or postdoctoral students or from RTOs) to perform research activities covering such needs (Figure 2). While this approach has been successful so far due to the close connection between the partners, challenges concerning the different time perspectives in industry and academy emerged. For universities have mostly long-term perspectives due to the need for satisfying research projects requirements, companies often have the need for capitalizing on innovation projects on a short-term. Nevertheless, following the same structure, the MADE FAST program is expected to be launched in 2020, focusing its activities on answering the need for responsiveness emerged from MADE industrial partners.

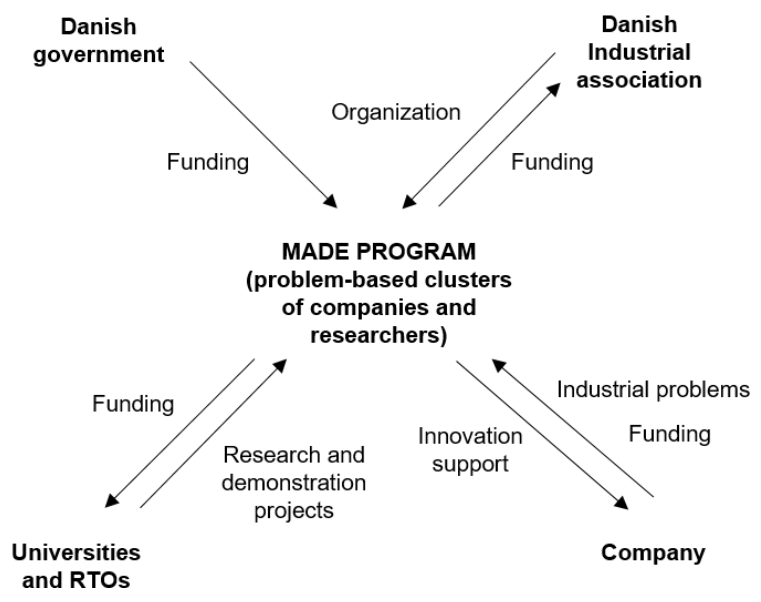

Figure 2. Structure of the Danish agenda 


\section{Case studies}

Four case studies are reported in the following. The first two case companies are Italian discrete manufacturers from the Lombardy region, one of the most industrialized area in Europe, with a strong focus on manufacturing. The two last case companies are two of the biggest Danish discrete manufacturers. The case studies are presented describing the digital transformation strategic approach adopted by each company addressing the different points presented in the information mapping framework.

\subsection{Case 1 (Lombardy, Italy)}

The first case consists of a large discrete manufacturer operating worldwide as an automotive supplier. The collected data come from multiple research projects performed with the company. Secondary data are also have been collected from a previous paper investigating the company's digital transformation (see [22]).

The company established in 2015 its own Industry 4.0 internal agenda, to improve the company's productivity. The focus on this agenda has been put on IoT as an enabler of a collaborative environment - and structured data collection and analysis - that is meant to further support the lean practices adopted by the company. To manage and operationalize the activities concerning the Industry 4.0 agenda, a dedicated team consisting of "Digital Factory Project Managers" for managing the different activities and of "Digital Factory Engineers" for executing them, has been established. This dedicated team has identified and started, during this four years, several activities related to Industry 4.0, which have been performed in parallel. Each project involves the realization of proof of concepts (PoC) that make possible to evaluate the functionalities and performance of digital solutions and to formulate a business case to assess, in particular, their profitability and return of investment. The PoC are realized and tested in the Italian company's factory to facilitate organizational learning and, in case of successful implementation, rolled-out worldwide. Currently, more than 50 activities related to the Industry 4.0 agenda are being performed. In order to build internal competences concerning the newly implemented solutions, the company integrated in its training laboratory a section (which currently represents half of it) concerning Industry 4.0.

Within production operations, these $\mathrm{PoC}$ are focused on the current manufacturing and assembly departments, along with quality control and maintenance activities. The two main objectives concerned the improvement of quality performance and the reduction of production lead time and rampup time for new technologies. These have been successfully addressed respectively through of the increase of process automation (e.g. machining and powder coating) and through the enabling of transparency across production through the deployment of an IT infrastructure aiming at collecting information for the support of human operations (e.g. production and quality control, elearning, smart tool management). In the near future, the company expects to increase further its degree of automation through the introduction of autonomous guided vehicles (AGVs) to automate internal logistics and of a new automation system to enable an autonomous setup of the machines on the production floor.

\subsection{Case 2 (Lombardy, Italy)}

The second case consists of a large discrete manufacturer, part of a multinational corporation, operating worldwide in heavy electrical equipment. The collected data come from a company visit and a discussion with the plant's strategic business development manager. As the addressed plant is one of the four lighthouse plants for Industry 4.0 in Italy, its innovation projects are partly financed by governmental funding.

The company started its digital transformation in 2008, when an extensive lean manufacturing transformation project was initiated, intending to improve plant competitiveness over both competitors as well as internally, over other company plants. The current activities, related to the Industry 4.0 agenda, are closely related to the lean transformation and are seen as a direct continuation of that process, operationalized through the integration of digital technologies in production. The transformation has been operationalized internally and supported by a local industrial consortium the company is part of. Several pilot projects concerning the application of all the different Industry 4.0 enabling technologies [14] has been run in the production environment. Part of the use cases concerning the integration of such technologies for generating value has also been inspired by startups that have been acquired by the company. Some of these technologies are now partly used as demonstrators and only partly integrated into normal production operations, while others have been scaled and well-accepted as integral parts of production operations, mainly deployed on the most advanced production line in the factory. The training concerning their use is supported through the 
establishment of external partnerships with specialized consulting firms and the use of training software. Furthermore, through the collaboration with technical schools, the company is supporting thesis projects and, at the same time, training future candidates (e.g. programmers) to the integration of digital technologies in the existing production environment: a key task concerning the company's digital transformation. Nevertheless, the main challenge concerning the company's digital transformation agenda is related to the ability to sustain this constant innovation and change.

Within production operations, the digital transformation has been addressing the need for increasing operational performance and production capacity while dealing with a high degree of product customization, as most of the products are different from each other. The two main points addressed by the company concern the monitoring and control of manufacturing processes and the automation of internal logistics. In regards to the monitoring aspect, it consisted in the collection of process data (e.g. order number, process number, cycle times and quality control) and in their visualization on a digital lean board for facilitating the identification of issues to be addressed. Production control has been supported through an internally developed manufacturing execution system (MES) interconnecting production orders and resources with the components' suppliers - located in the same plant - and the logistic system. This made possible to automate the components' supply process and the resources configuration to satisfy incoming orders. The automation of internal logistics consisted in the introduction of autonomous guided vehicles (AGVs), connected with the MES, for finding and transporting components to the production line according to its needs. The automation of such processes is transforming the plant from being labor-intensive to a capital intensive one. This is generating the demand for indirect tasks and related competences to support the automated core processes (e.g. maintenance). As a consequence of that, a future project concerns the integration of a computerized maintenance management system for supporting, through the use of data available in the MES, maintenance activities.

\subsection{Case 3 (Denmark)}

The third case consists of a large multinational company, operating worldwide in the pharmaceutical sector but with its headquarters in Denmark. This case focuses on the plant which is taking care of the manufacturing of some of the company's core products and acts as a ramp-up factory when new products are introduced. The collected data come from a company visit, official documentation and multiple interviews to digital transformation responsible during a digital maturity assessment performed by some of the authors.

The company started in 2018 to structure its digital transformation activities around the Industry 4.0 agenda. The transformation started from the Danish headquarters and so far has been addressed independently in the different company business units by cross-department teams. The company took advantage of its collaboration with a university for performing a digital maturity assessment to identify focused initiatives for addressing its strategic goals. The identified goals concerned production cost reduction and the improvement of ramp-up time related to the introduction of new technological solutions or production practices. Competence-wise, the latter is currently supported by sharing, as internal training material, videos concerning the optimal performance of the production activities. In order to address production cost reduction, the engaged activities concerned the introduction of an IT system capable of collecting data concerning production operations and of a digital lean board on the production floor, providing an overview of production KPIs and highlighting eventual issues and maintenance needs. Ramp-up time improvement has been addressed through the introduction of an agile approach for managing innovation projects - today slowed down by management complexity - as well as a dedicated environment (e.g. learning laboratory) for facilitating technology implementation pilots - today limited by strict production regulations - as well as the training concerning the use of such technologies. The company is currently planning to use data concerning product tolerances obtained during the manufacturing processes to adjust the assembly process reducing the time needed to match them. Another future project concerns the introduction of AGVs for the automation of internal logistics. Furthermore, the company is joining the national consortium supporting the digital transformation of the Danish manufacturing industry and facilitating research projects with universities within this domain.

\subsection{Case 4 (Denmark)}

The fourth case consists of a large multinational cooperative, with its headquarters located in Denmark, operating globally in the food sector. A particularity of the company is that this has control over almost its entire supply chain, from the raw material producers to the distribution (included) of 
the finished product to shops that are selling it to the actual consumers. The collected data come from multiple company visits, discussions concerning the digital transformation with the company management, company material concerning the company's digital transformation journey and several projects the authors directly performed with some of the producers of the cooperative.

The company started in 2017 its digital transformation program. The transformation started in the company headquarters and its focus was mostly on data and on how to enable transparency across the company's supply chain. The company, part of a national consortium for the industrial digital transformation, addressed it through a crossdepartment team, with a number of hours allocated for projects concerning the Industry 4.0 agenda. The team took advantage of the partners involved in this consortium, such as universities (Ph.D. students), RTOs and technology providers, for supporting its digital transformation projects. A small number of parallel pilot projects concerning the implementation of new digital technologies, to address actual needs within the firm, has been identified and performed.

Within production operations, the initial activities were focused on production cost reduction. This was supported by the introduction of a cloud-based digital platform aiming at enabling transparency across the company's supply chain. This was based on the ISA95 standard in order to support interoperability and a potentially "plug and play" introduction of future infrastructure entities. The objective was to interconnect the dairies to the headquarters, providing the latter with a global overview of operational performance. This provided the foundation for addressing cost reduction through activities related to the manufacturing, quality control and logistics areas, starting from PoC tested in lighthouse plants. In regards to manufacturing and quality control, a project concerning the use of available quality data and process data from the different manufacturing process, to identify and verify the waste root causes and reduce them, have been performed. In regards to logistics, other than the testing of $\mathrm{AGVs}$ for the automation of internal transportation, pilot projects concerned the optimization of the external logistics planning through the use of data concerning production and the reduction of cost concerning external logistics by reducing, through the enabling of remote tracking, the losses of materials supporting the transportation of the goods. Future activities concern the increase of data processing capabilities through the extensive use of analytics at first in the logistics and planning areas.

\section{Discussion}

The research is reaffirming, also within the industrial digital transformation domain, the influence context and policy dimension have in determining innovation practices [6]. The strong emphasis on subsidy characterizing the Italian context is reflected in the transformation strategy of the two Italian companies addressed in this research, which are focusing on the adoption of new technologies for either automating their processes (e.g. AGVs for internal logistics and manufacturing process automation). On the contrary, the two Danish companies focus their activities on understanding how to adapt their way to address innovation projects to a digital era and how to translate the availability of data across their supply chains into further business value (e.g. logistic equipment tracking). This is operationalized through a vast amount of explorative projects supported by the Danish industrial context focusing on knowledge building, through wellestablished synergies and close collaborations between industry, RTOs and academic institutions. It is worth to consider that the Italian industrial policies are moving towards the realization of a structured system - similar to the one which is being used in Denmark - for facilitate knowledge building and supporting companies more holistically in addressing their digital transformation, taking advantage of synergies with academic institutions. This, in contrast with the technology-focused strategy adopted during the past years and in line with the need for a more holistic and strategic focus identified by late research [4] [5], could represent the most appropriate way to deal with this transformation at a national level in Europe.

Independently from the diverse context, there are sensible key commonalities amongst the investigated companies' digital transformation agenda. These are related to their shared interest in improving their responsiveness and in reducing their production costs. Such objectives are addressed, independently from the context, by empowering humans, supporting their decision making processes with digital means (e.g. production monitoring and control, quality issues identification, e-learning). Furthermore, for all investigated companies, most of the digital transformation activities consist of brownfield projects, concerning the digitalization of already existing processes. This is characterizing the digital transformation of these firms as evolutionary, not revolutionary. Even if in different ways, this evolution is sustained in both national contexts (i.e. knowledge deployment) either (i.e. Italy) through the provision of financial support for hiring consultants 
with expertise in the field, either (i.e. Denmark) through financial support for demonstration projects, awareness workshops and training sessions from research institutions and RTOs. The common absence of institutional directives towards the adoption of standards could, however, act as a limitation for achieving interoperability across different companies and, as a consequence of that, for catalyzing the digital transformation at a supply chain level.

Although this paper is presenting commonalities and diversities amongst digital transformation strategies in different contexts, in order to evaluate their actual effectiveness it is necessary to verify their impact on the companies' operational performance. Furthermore, even though large multinational companies have been considered as they are farther in their digital transformation journey, they are also less dependent on their national context (i.e. exogenous factors) due to their global nature. In addition to that, the limited amount of investigated industrial cases limits the emerged endogenous factors and the understanding of their link with the exogenous factors.

\section{Conclusion}

The outset of this paper was to investigate the different digital transformation strategies adopted in large manufacturing companies from different countries. This investigation has been performed to provide an empirical understanding concerning the link between the framework conditions (i.e. exogenous factors) companies operate in and the different transformation strategies internally adopted by them to support their digital transformation (i.e. endogenous factors). This paper aims, therefore, at contributing to the existing knowledge concerning transformation strategies, with an outlet in the Industry 4.0 agenda, by addressing the contingency aspect, crucial element to be studied for building an understanding of the reason behind the adoption of such strategies [7].

This cross-country evaluation suggests that some strategic elements, such as the need for a structured approach, its evolutionary (and not revolutionary) being, the enabling of synergies between industry and research institutions the focus on automating business processes and the use transparency to support human operations, are shared amongst different companies (i.e. endogenous factors), independently from the national context and its industrial policies (i.e. exogenous factors). In regards to the latter, a key aspect that emerged concerned the limitations related to a national strategy based on financial support focused on the acquisition of technology assets only.
At a company level, this led to a high number of pilot projects concerning the integration of new technologies but generated a need for further financial support to cope with the competence gap generated by the prompt introduction of these technologies.

Although relevant findings concerning different digital transformation strategies, as well as their dependencies from exogenous factors, emerged from this investigation, a higher number of cases would be beneficial for increasing the understanding of such dependencies and the robustness of the research outcome. Furthermore, to perform this investigation with SMEs would possibly offer further aspects to be considered, and make it possible to obtain a clearer distinction between digital transformation strategies in diverse contexts. In addition to that, a study of the effectiveness of the adopted strategies in the different contexts would provide practitioners with further support concerning the identification of the digital transformation strategy to be adopted.

\section{References}

[1] McKinsey Report. (2015). How to Navigate Digitization of the Manufacturing Sector.

[2] Davies, R. (2015). Industry 4.0 Digitalisation for productivity and growth. European Parliamentary Research Service, 10.

[3] Liao, Y., Loures, E. R., Deschamps, F., Brezinski, G., \& Venâncio, A. (2018). The impact of the fourth industrial revolution: a cross-country/region comparison. Production, 28.

[4] Westerman, G. (2018). Your Company Doesn't Need a Digital Strategy. MIT Sloan Management Review, 59(3), 15.

[5] Kane, G. C., Palmer, D., Phillips, A. N., Kiron, D., \& Buckley, N. (2015). Strategy, not technology, drives digital transformation. MIT Sloan Management Review and Deloitte University Press, 14, 1-25.

[6] Lundvall, B. Å., Johnson, B., Andersen, E. S., \& Dalum, B. (2002). National systems of production, innovation and competence building. Research policy, 31(2), 213-231.

[7] Sousa, R., Voss, C. (2008). Contingency research in operations management practices. J. Oper. Manag. 26 (6), $697 \mathrm{e} 713$.

[8] Nightingale, A. (2009). A guide to systematic literature reviews. Surgery (Oxford), 27(9), 381-384. http://dx.doi.org/10.1016/j. mpsur.2009.07.005. 
[9] Pickering, C., \& Byrne, J. (2014). The benefits of publishing systematic quantitative literature reviews for $\mathrm{PhD}$ candidates and other early-career researchers. Higher Education Research \& Development, 33(3), 534-548. http://dx.doi.org/10.1080/07294360.2013.841651.

[10] Corrocher, N., \& Ordanini, A. (2002). Measuring the digital divide: a framework for the analysis of crosscountry differences. Journal of Information technology, 17(1), 9-19.

[11] King, J. L., Gurbaxani, V., Kraemer, K. L., McFarlan, F. W., \& Raman, K. S. Y., C.S. (1994). Institutional Factors in Information Technology Innovation. Information Systems Research, 5(2), 139-169.

[12] Yin, R. K. (2017). Case study research and applications: Design and methods. Sage publications.

[13] Eisenhardt, K. M. (1989). Building theories from case study research. Academy of management review, 14(4), 532-550.

[14] Matt, C., Hess, T., \& Benlian, A. (2015). Digital transformation strategies. Business \& Information Systems Engineering, 57(5), 339-343.

[15] Colli, M., Madsen, O., Berger, U., Møller, C., Wæhrens, B. V., \& Bockholt, M. (2018). Contextualizing the outcome of a maturity assessment for Industry 4.0. Ifacpapersonline, 51(11), 1347-1352.

[16] Mykhaylenko, A., Motika, Á., Waehrens, B. V., \& Slepniov, D. (2015). Accessing offshoring advantages: what and how to offshore. Strategic Outsourcing: An International Journal, 8(2/3), 262-283.

[17] Waehrens, B. V., Slepniov, D., \& Johansen, J. (2015). Offshoring practices of Danish and Swedish SMEs: effects on operations configuration. Production Planning \& Control, 26(9), 693-705.

[18] Italy. Ministry of Economic Development - MISE. (2016). Piano nazionale industria 4.0 [National industry 4.0 plan]. Rome: Ministry of Economic Development. Report.

[19] European Commission. (2018). Digital Transformation Scoreboard. Retrived from https://ec.europa.eu/growth/toolsdatabases/dem/monitor/sites/default/files/Digital\%20Transf ormation\%20Scoreboard\%202018_0.pdf.

[20] Rüßmann, M., Lorenz, M., Gerbert, P., Waldner, M., Justus, J., Engel, P., \& Harnisch, M. (2015). Industry 4.0: The future of productivity and growth in manufacturing industries. Boston Consulting Group, 9(1), 54-89.

[21] Johansen, J; Madsen, O., Jensen, H. V., Vestergaard, A., (2010). Manufacturing 2025 - Five scenarios for Danish manufacturing companies. Department of Mechanical and Manufacturing Engineering, Aalborg University.

[22] Powell, D., Romero, D., Gaiardelli, P., Cimini, C., \& Cavalieri, S. (2018). Towards digital lean cyber-physical production systems: Industry 4.0 technologies as enablers of leaner production.

Table 1. Exogenous factors: national contexts in Italy and Denmark

\begin{tabular}{|c|c|c|}
\hline & Italy & Denmark \\
\hline $\begin{array}{l}\text { Knowledge } \\
\text { building }\end{array}$ & $\begin{array}{l}\text { Universities performing research addressing } \\
\text { the development of digital technologies }\end{array}$ & $\begin{array}{l}\text { Universities and RTOs performing research } \\
\text { projects addressing companies' digital } \\
\text { transformation needs, aligned by the industrial } \\
\text { association in a common platform }\end{array}$ \\
\hline $\begin{array}{l}\text { Knowledge } \\
\text { deployment }\end{array}$ & $\begin{array}{l}\text { Universities and industrial association } \\
\text { assessing companies' digital capabilities } \\
\text { innovation managers advising companies in } \\
\text { regards to transformation practices (Future: } \\
\text { support through competence centers, digital } \\
\text { innovation hubs and digital enterprise points) }\end{array}$ & $\begin{array}{l}\text { University laboratories performing awareness } \\
\text { workshops and training sessions, universities } \\
\text { and RTOs performing demonstration projects } \\
\text { and industrial association organizing knowledge } \\
\text { dissemination events }\end{array}$ \\
\hline Subsidy & $\begin{array}{l}\text { Financial incentives for the acquisition of new } \\
\text { technology assets capable of generating and } \\
\text { processing digital data }\end{array}$ & - \\
\hline Mobilization & $\begin{array}{l}\text { Institution of a national program (i.e. Piano } \\
\text { Industria 4.0) }\end{array}$ & Institution of a national program (i.e. MADE) \\
\hline $\begin{array}{l}\text { Standard } \\
\text { setting }\end{array}$ & - & - \\
\hline $\begin{array}{l}\text { Innovation } \\
\text { directive }\end{array}$ & - & - \\
\hline
\end{tabular}


Table 2. Endogenous factors: digital transformation strategy in the four case companies

\begin{tabular}{|c|c|c|c|c|c|}
\hline Dimension & $\begin{array}{l}\text { Sub- } \\
\text { dimension }\end{array}$ & Case 1 (IT) & Case 2 (IT) & Case 3 (DK) & Case 4 (DK) \\
\hline \multirow[t]{2}{*}{ Governance } & Pilot strategy & $\begin{array}{l}\text { Many parallel } \\
\text { pilots: } \\
\text { development and } \\
\text { testing in } \\
\text { production and } \\
\text { economical } \\
\text { evaluation of PoC } \\
\text { before roll-out }\end{array}$ & $\begin{array}{l}\text { Many parallel } \\
\text { pilots: } \\
\text { development and } \\
\text { testing in } \\
\text { production at the } \\
\text { lighthouse } \\
\text { factories }\end{array}$ & $\begin{array}{l}\text { Few parallel } \\
\text { pilots: } \\
\text { development } \\
\text { and testing in } \\
\text { protected } \\
\text { environments }\end{array}$ & $\begin{array}{l}\text { Few parallel } \\
\text { pilots: } \\
\text { development and } \\
\text { testing in } \\
\text { production at the } \\
\text { lighthouse } \\
\text { factories }\end{array}$ \\
\hline & $\begin{array}{l}\text { Transfor- } \\
\text { mation } \\
\text { team }\end{array}$ & - & $\begin{array}{l}\text { Consulting for } \\
\text { training, } \\
\text { consortium for } \\
\text { development and } \\
\text { technical schools } \\
\text { for recruiting and } \\
\text { training }\end{array}$ & $\begin{array}{l}\text { Universities } \\
\text { through } \\
\text { research } \\
\text { projects at the } \\
\text { point of demand }\end{array}$ & $\begin{array}{l}\text { Technology } \\
\text { providers, RTOs } \\
\text { and universities } \\
\text { through ongoing } \\
\text { research and } \\
\text { student projects }\end{array}$ \\
\hline \multirow[t]{4}{*}{ Value creation } & Scope & $\begin{array}{l}\text { Manufacturing, } \\
\text { assembly, quality } \\
\text { inspection and } \\
\text { maintenance }\end{array}$ & $\begin{array}{l}\text { Planning, internal } \\
\text { logistics and } \\
\text { assembly }\end{array}$ & $\begin{array}{l}\text { Assembly, } \\
\text { innovation } \\
\text { management }\end{array}$ & $\begin{array}{l}\text { Manufacturing, } \\
\text { quality control and } \\
\text { logistics }\end{array}$ \\
\hline & Objective & $\begin{array}{l}\text { Extended } \\
\text { potential } \\
\text { enabling }\end{array}$ & $\begin{array}{l}\text { Extended } \\
\text { potential enabling }\end{array}$ & $\begin{array}{l}\text { Extended } \\
\text { potential } \\
\text { enabling }\end{array}$ & Problem solving \\
\hline & Mechanism & $\begin{array}{l}\text { Process } \\
\text { automation } \\
\text { (coating, } \\
\text { machining) and } \\
\text { human operations } \\
\text { support (quality } \\
\text { issues } \\
\text { identification, } \\
\text { setup planning, e- } \\
\text { learning) }\end{array}$ & $\begin{array}{l}\text { Process } \\
\text { automation (order } \\
\text { management, } \\
\text { planning, internal } \\
\text { logistics) and } \\
\text { human operations } \\
\text { support } \\
\text { (performance } \\
\text { issues } \\
\text { identification) }\end{array}$ & $\begin{array}{l}\text { Agile innovation } \\
\text { project } \\
\text { management } \\
\text { (ramp-up), } \\
\text { human } \\
\text { operations } \\
\text { support (process } \\
\text { documentation, } \\
\text { e-learning) }\end{array}$ & $\begin{array}{l}\text { Human operations } \\
\text { support } \\
\text { (traceability for } \\
\text { recovering lost } \\
\text { material and } \\
\text { waste reduction } \\
\text { support) and } \\
\text { process } \\
\text { automation } \\
\text { (internal logistics) }\end{array}$ \\
\hline & $K P I$ & Speed and quality & Speed & Speed and cost & Cost \\
\hline Competences & $\begin{array}{l}\text { Compe- } \\
\text { tences } \\
\text { development }\end{array}$ & $\begin{array}{l}\text { Internal learning } \\
\text { laboratory where } \\
\text { training sessions } \\
\text { are held, e- } \\
\text { learning }\end{array}$ & $\begin{array}{l}\text { Training session } \\
\text { supported by a } \\
\text { consulting firm } \\
\text { and by a software }\end{array}$ & $\begin{array}{l}\text { Video } \\
\text { documentation } \\
\text { for training }\end{array}$ & - \\
\hline Technology & $\begin{array}{l}\text { Data } \\
\text { processing } \\
\text { capabilities }\end{array}$ & $\begin{array}{l}\text { Information } \\
\text { availability } \\
\text { according to value } \\
\text { stream needs }\end{array}$ & $\begin{array}{l}\text { Information } \\
\text { availability } \\
\text { according to value } \\
\text { stream needs and } \\
\text { automatic data } \\
\text { processing }\end{array}$ & $\begin{array}{l}\text { Information } \\
\text { availability } \\
\text { according to } \\
\text { value stream } \\
\text { needs }\end{array}$ & $\begin{array}{l}\text { Information } \\
\text { availability } \\
\text { according to value } \\
\text { stream needs and } \\
\text { introduction of } \\
\text { analytics } \\
\end{array}$ \\
\hline Connectivity & Integration & Vertical & $\begin{array}{l}\text { Both vertical and } \\
\text { horizontal with } \\
\text { close suppliers }\end{array}$ & Vertical & $\begin{array}{l}\text { Both vertical and } \\
\text { horizontal within } \\
\text { the controlled } \\
\text { supply chain }\end{array}$ \\
\hline
\end{tabular}

